\title{
Heterarchies and Developmental Traps
}

\author{
Heterarquias e as armadilhas de desenvolvimento
}

LASZLO BRUSZT*

RESUMO: A capacidade do Estado de resistir a poderosos grupos econômicos predadores depende muito da maneira como a diversidade social é representada dentro da sociedade. Essa capacidade estatal é fraca quando um único ramo do governo pode usurpar a representação do bem público entre duas eleições. Em algumas democracias que chamo de heterarquias, parceiros de coalizão, partidos em diferentes casas do legislativo, diferentes níveis e ramos do governo, agências estatais autônomas obrigam os executivos a levar em conta diversos modos de representação enquanto fazem seus programas e políticas. Tais restrições à autoridade executiva permitem que o Estado supere a distribuição direta de poderes e interesses na economia. No artigo, uso o caso russo para analisar a relação entre a fraqueza do Estado e os problemas relacionados ao desenvolvimento econômico.

PALAVRAS-CHAVE: Economia política; heterarquia; desenvolvimento econômico; economia em transição.

ABSTRACT: State capacity to resist powerful predatory economic groups is highly dependent on the way social diversity is represented within the polity. Such state capacity is weak when a single branch of government can usurp the representation of public good between two elections. In some democracies that I call heterarchies, coalition partners, parties in different houses of the legislature, different levels and branches of government, autonomous state agencies compel executives to take into account diverse modes of representation while making their programs and policies. Such constraints on executive authority allow the state to rise above the direct distribution of powers and interests within the economy. $\ln$ the paper I use the Russian case to analyze the relationship between state weakness and the related problems of economic development.

KEYWORDS: Political economy; heterarchy; economic development; transitional economy. JEL Classification: P26; D72; D73.

\footnotetext{
* Sociologist, Associate Professor, Department of Political Sciences, Central European University, Budapest, Hungary. E-mail: brusztl@gmail.com. Orcid https:/orcid.org/0000-0001-7624-0308.
} 
The parallel extension of property rights and citizenship rights in the postcommunist countries can be interpreted as the simultaneous introduction of rights allowing the constitution and preservation of universal economic freedoms, and, at the same time, social regulations constraining these freedoms. To put it differently, in postcommunist countries, the re-politicization of economic activity making it a private business protected by rights against political interference and the democratic re-politicization of economic reproduction happens at the same time.

The extension of citizenship rights might be seen as not only compatible with, but also as necessarily complementing the extension of property rights. Citizenship rights allow for the imposition of 'beneficial constraints' on economic freedoms (Streeck 1997). Sometimes pure efficiency considerations concerning the improvement of economic performance, for example in order to prevent the misuse of asymmetries in economic and informational power, may contribute to the imposition of citizenship rights and also the constitution and preservation of competition (Commons 1924; Samuels 1992). Some of the other constraints, like the regulation of social rights, do not necessarily pursue efficiency, but rather serve the reproduction of social integration, necessary for the development of market order (Durkheim 1989). Finally, a third group of constraints, including environmental regulations or the regulation of the norms of fair employment may not directly pursue economic goals, but nevertheless improve the adaptability of the economy (Streeck 1997).

The parallel extension of property rights and citizenship rights might be incompatible with each other to the extent that self-interested private groups have the possibility of seizing political power in order to distribute wealth and opportunities in their own favor. In this paper I will argue that this may happen because democratization of the state is too slow and limited, not because the democratization of the political regime is too fast and too extensive. Democratization of the political regime, 1 will argue, more often than not decreases the probability of representing within the state particularistic considerations solely. The logic of the competitive party democracy and the accountability of representatives, be they individuals or political parties, puts a strong pressure on representatives to find ways of accommodating in a balanced way the biggest diversity of heterogeneous interests (Offe 1984; Stark and Bruszt 1998). Representatives do not only re-present in the state the actual distribution and intensity of preferences within the society. Acting under the pressure of the logic of political competition, they are forced to 'refine and enlarge public views', to accommodate the biggest number of diverse interests in their programs in a balanced way ${ }^{1}$ As a 'by-product', this organiza-

\footnotetext{
${ }^{1}$ It was Madison who first thought of specific forms of representations to produce different contents and change citizens' preferences, oras he put it, to 'refine and enlarge the public views'. (Hamilton et ai. 1961).
} 
tional form of universal political inclusion reduces the danger of incompatibility between the extension of property rights and citizenship rights (Offe 1984).

Democratization of the political regime alone, however, cannot prevent the capturing of the state by powerful economic groups representing particularistic interests if the organization of decision making within the state is not sufficiently democratic. Decision-making within the state is more or less democratic depending on how the process of representation is structured within the state. This depends partly on the organization of modes of representation, and partly on the design of relationships among different representative institutions. In some of the new democracies, coined by O'Donnell as delegative democracies, modes of representation and relations among representative institutions allow a single branch of government to usurp the representation of public good (O'Donnell 1994). In other democracies, incumbents are embedded in a network of interdependent and autonomous institutions expressing different modes of representing the public good. ln the process of policy making, government executives here have to take into account diverse conceptions of the public good resulting from different modes of representation in the institutions. 1 would call such democracies heterarchies ${ }^{2}$ in a heterarchy, voters' rights to delegate directly or indirectly yield diverse representations of the public good within the state and a balanced distribution of decision making rights among the different representative institutions extends the accountability of executives and prevents any actor or institution of the state from monopolizing the representation of public good.

The capacity of states to resist powerful particularistic groups is weak when there is little diversity in the representation of the public good by autonomous state institutions and executive power is too much concentrated. In that event, the government can take decisions unilaterally without considering diverse representations of the public good advanced by state and non-state actors through democratic institutions. In a heterarchy, the extended accountability of executives reduces the chance of the representation of particularistic group interests in public policy. In a heterarchy, coalition partners, parties in different houses of the legislature, different levels and branches of government, autonomous state agencies, and organizations of civil and economic society compel executives to take into account diverse modes of representation while making their programs and policies. lt is through such constraints on executive authority that a heterarchy allows the state to rise above the direct distribution of powers and interests within the economy.

Heterarchies can counter-balance the pressure of particularistic groups in policy making such that they produce orderly and temporary accommodations of diverse social and economic interests. By orderly, I mean that the accommodation

\footnotetext{
2 The concept of heterarchy draws partly on our severa! discussions with David Stark while working on our book on postcommunist transformations, and partly on the innovative way Stark used this concept in the field of economic sociology in one of his newest papers (Stark 1999; Stark and Bruszt 1998).
} 
of diverse interests happens in the framework of an encompassing program about transforming or conserving the economy and society. By temporary I solely mean that these programs never become stable equilibrium points, and political actors in heterarchies have to continuously renew their alliances, find newer ways of associating diverging interests and thus creating novel balances. It is the continuous fight and competition among different representative institutions that allows time to re-balance relationships among the various representative institutions, and thus create new policies adapting to changing interests.

In this paper, 1 will argue that there is a homology between the state organization and the patterns of economic development. Countries that are less heterarchic and less able to produce balanced policies are easy prey for particularistic interests and thus contribute to imbalances if not to blockages of economic development. On the other hand, regimes whose institutions foster policies balancing interests are not the hostages of the actual distribution and intensity of preferences within the society. Instead, they have the capacity of re-balancing power relations within the economy and contribute to inclusive economic development. Diversifying the representations of the public good within the polity and extending the accountability of government executives can thus contribute to the diversification of options of economic development, and can increase the overall adaptability of the economy. In the first part of the paper, I will deal with the different mechanisms of balancing within the political regime and the state. First, 1 address the question how democratization of the political regime might contribute to the creation of the conditions for the state to create balanced decisions and thus increase its capacity to (re)constitute a balanced economic order. I will argue that the introduction of free and fair elections, the principle of "one man one vote", may contribute to improving balanced economic policies, but it does not constitute a sufficient condition for this outcome. A host of other factors affects the capacity of state actors to abuse their power arbitrarily and also that of non-state actors to abuse political authority. Many of the new democracies in Eastern Europe are poliarchies in the sense Dahl has introduced, but not heterarchies. While they are democratic political regimes in the Dahlian sense, existing modes of representation permit powerful economic actors to use the state for the furthering of their particularistic interest (Dahl 1971). In the second part of the paper, I will discuss economic developments in Russia since the introduction of the first package of neo-liberal reforms. The Russian case, I will argue, is a primary example for the developmental trap that might emerge when a state lacking the institutional capabilities to organize an accommodation of interests introduces neo-liberal reforms.

\section{2.}

Nothing is further from the reality of competitive party politics than the view of pluralists conceiving of the representative process as the mere aggregation of people's distribution and intensity of actual preferences (Dahl 1956; Downs 1957). 
It is the very logic of representation within a competitive political framework that alters the content of representation and forces players within the political field to produce a diversity of representations of public good that are based on different recombinations of actual preferences, representing their different balances (Bourdieu 1981; Offe 1984; Stark and Bruszt 1998).

In a democratic political regime, the most basic element of balancing has to do with representation and accountability (Stark and Bruszt 1998). Actors in the political field, parties and politicians open accounts and they make accounts. They appeal to the electorate: 'put your credit on my account, credit me, authorize me to act on your account, give me the power to represent your interests'. To get credited, they produce programs, specific forms of narration, accounting. To maximize their credits/support, they try to take into account he biggest number of diverse interests. However, they do not simply act on the conflicting investment strategies preferred by each depositor with her special interests. They cannot just represent these divergent interests as they are given. Because the resulting contradictory strategies would discredit them, they instead seek to transform citizens' self-conceptions of interests with the objective to find innovative ways of linking them by forging new types of associations among social forces and cognitive understandings. To improve their balances, they have to find ways of associating diverse interests in a balanced way. In that process, they also change the framework in which people define their interests and identities. Like encompassing, mixed investment strategies, political programs are therefore doubly associative. In making claims to represent, to speak on behalf of named social groups (e.g. "We are the party of labor AND small business"); they attempt to create alliances. But they also propose courses of action that attempt to modify the interests themselves and their patterns of interaction (e.g. "We are the party of social contract, of the big developmental alliance: moderate wage demands accepted by labor can raise profitability and export performance, thereby increasing the level of investment and securing government revenues, thereby upgrading infrastructure and investment in human capital, leading to stabilization of employment and increases in wages in the framework of stable economic growth") (Stark and Bruszt 1998).

Successful programs result from the deliberate association of previously separate interests and identities; they break the boundaries of previously fixed social groups. Such alliance building and transformative policy programs thus are functional equivalents for what proponents of participatory democracy have strived to achieve: a deliberative process in which actors with diverse interests and identities are ready to give up their fixed positions and ally their identities by way of deliberative association among the constituency groups (Stark and Bruszt 1998; Sunstein 1985).

Considering the biggest diversity of interests in a balanced way, is not the sole condition that makes citizens entrust political actors with their support. While attracting commitments and resources through programmatic appeals, they have to position themselves in relation to competing politicians and their programmatic projects (Bourdieu 1981). If they want people to identify with their program, they 
have to have an identity. They cannot just represent anything. If they do not want to lose their support and resources, they have to represent divergent interests in an identifiable way, i.e. they have to position themselves by way of distinction. That also allows them to discredit those who do not even have an identifiable position or those who change their positions in an opportunistic way. Taking an identifiable position in the political field on changing or maintaining the social order means that politicians produce in a competitive political field a structured diversity of the representations of public good, i.e. diverging associations of social categories and functions. To stay in the political field, politicians must offer a distinctive conception of the public good superseding a mere aggregation of the most encompassing and diverse common denominator of public interests.

Several other factors might result in divergent representations of the public good. A president elected directly by the nation has to accommodate a different set of divergent interests, and thus will have a different representation of the public good, than a legislator elected in a single district, or another one, elected on a party list. The size of the constituency might alter the nature and content of representation. As already Madison noted, the smaller the size of the constituency to be represented, the bigger the chance that the representative will just re-present the interests and passions of particular factions. Conversely, if the constituency is too large, one can hardly speak of the accountability of the representa tive (Hamilton et ai. 1961). The method of election might also alter the content of representation of the public good. Elections under proportional mies might be more 're-presentative' in the sense that they might make present the plurality of views, ata more dis-aggregated levei. Elections under majoritarian electoral rules, on the other hand, might be more 'representative', in the sense that they are more likely to produce representations of public good that are based on the association of the biggest diversity of interests.

None of the methods of elections may produce the 'best' representation of public good, they produce different ways of representing public good, and all have advantages and disadvantages. Similarly, there is no single constituency size able to produce the 'best' representation of the public good. Yet, it is certainly a public good to permit a diversity of representations of the public good. It is this diversity, that is the basic safeguard against the usurpation of the representation of public good by any single group or actor. Electoral accountability might prevent representatives from merely re-presenting particularistic interests by forcing them to take into account diverse interests. Instituting diverse modes of representation, however, limits the capacity of any particular representative to further solely a particularistic representation of the public good, to speak alone in the name of the 'People'. Mixed political regimes constitute attempts to 'diversify the portfolio' of representations of the public good. Electoral regimes based on the mixture of proportional and majoritarian principies, combined with a bicameral body of representation with representatives for the two houses elected by constituencies of different size, might offer a more balanced set of representations of the public good, than simple presidential regimes (Linz and Stepan 1996). A balanced political regime builds on the 
diversity of competing representations of the public good, each of them contributing to the increased accountability of the others. Thus accountability is the source of balanced representations, and the existence of diverse and competing representations reinforces accountability.

In many new democracies, after elections that delegate public authority to representative politicians, political institutions and processes fail to articulate a diversity of modes of advancing the collective good. In these democracies G. O'Donnell called delegative democracies, only a single representation of the public good dominates the working of the executive between elections (O'Donnell 1994). There are no mechanisms of forcing the incumbents to continuously re-balance their representation of public good, or even to stick to any extent to the original account - the delegated representative can basically do whatever pleases him/her (O'Donnell 1994). Under such circumstances, representation is arbitrary and precarious, resulting in weak accountability and a feeble credibility of the executive. Why would economic actors accept an un-accountable state? Why should citizens invest in the support of an executive that cannot make credible commitments, and that hence is not accountable? In the absence of mechanisms that force the executive to continuously accommodate a diversity of interests, the implementation of unmitigated executive political visions about socio-economic change tends to reproduce existing relations of domination within the political order. Because of the weakness of accountability, there are no guarantees that the state will not misuse its power, or that it will not be misused: there are no guarantees that rights will be honored, or that the interventions of the state will serve anything that can be justified as being a public good (O'Donnell 1994; Schedler 1999). The economic developmental consequences of the working of such states might be deleterious: the enforcement of rights is unpredictable, so are the policies of the executive. Since there is nothing that would elevate the state over particularistic interests, the state is an easy prey for powerful economic groups be they territorial or functional oligarchies. Once caught by them, these states might just re-present a single voice, the voice of the loudest and strongest, and thus instead of re-balancing the economy, the working of these states might contribute to the deepening of developmental traps (O'Donnell 1994).

Democratization of the political regime alone is not a sufficient condition for a balanced representation within the state. A host of institutions and behavioral patterns must be in place to extend the accountability of executives between two elections, to force them to make balanced representations of the public good their objective (Stark and Bruszt 1998). In such a state, policies and laws result from an orderly accommodation of heterogeneous rationalities, interests and considerations. I would call a heterarchy that specific type of democracy in which the structure of representation preserves the diversity of conceptions of the public good within the state between two elections and the balanced distribution rights among representative institutions forces executives to take into account heterogeneous interests while forming their policies.

ln a heterarchy, the delegative powers of the people are organized such as to prevent any representative, be it a person, a political party, a branch or level of 
government, from usurping the representation of the public good. From this perspective, simple majoritarian parliamentary regimes or strong presidential regimes are inferior compared to mixed political regimes. Mixed political regimes diversify the portfolio of the representations of popular interests. In such a regime, people's preferences find their way into multiple modes of representation. In bicameral parliaments with electoral mies that allow for the representation of both the plurality and the majority of 'passions and interests', two principies of representation are incorporated in the democratic process. Properly designed mixed electoral systems with proportional balances might be a basis of inserting balanced representation into the executives by making coalition governments more likely. The different branches and levels of the state also have diverse representations of public good. The separation of powers and the possibility of each branch and levei to defend its autonomy and prevent other levels and branches from the misuse of their autonomy further diversify the representation of public interests within the state. Altogether, a heterarchy presumes that no social or economic actor or group has the 'right' interests and that there is no single "correct" representation of diverse interests. The objective of heterarchical design is to uphold this diversity within the state, and prevent any actor or institution from monopolizing the representation of the public good.

In a heterarchy, the distribution of authority among representative institutions prevents concentration of power and with it, the representation in state policies of the interests of particularistic groups solely. $\ln$ such a system, executives are continuously forced to draft and implement inclusive policies supported by actors in diverse legislative organs, coalitional governments, parties in different houses of the legislature, different levels and branches of the government, autonomous state agencies, as well as associations in civil and economic society. lt is this permanent pressure on executives to take diverse conceptions of the public good into account in a balanced way that might allow the state to rise over the actual distribution of powers and interests within the economy.

Heterarchy is a constitutional order embodying a peculiar balance of the liberal, the democratic and the republican aspects of the state ${ }^{3} \ln$ this constitutional order, the democratic aspect of the state is strong because the delegative powers of the people are organized such that no single mode of representation will permanently reign supreme. $1 \mathrm{t}$ is distributed authority within the state that prevents any branch or levei of government from usurping the representation of public good. The republican aspect of a heterarchy, the extended accountability of politicians in the executive, forces them to be "virtuous" by removing the feasibility of special group interest, not by appealing to the goodness of politicians' heart. Such a constitutional order does not assume that representatives are 'angels' concerned solely about serving public good, or they are 'devils', as the public choice literature re-presents them, serving solely their selfish interests. Instead, in a heterarchy the extended ac-

\footnotetext{
${ }^{3}$ On these aspects of the state see the insightful analysis of G. O’Donnell (O’Donnell 1999).
} 
countability of executives forces incumbents to be 'virtuous', preventing them to re-present solely their narrow interests and forcing them to produce in their policies something that can be called public good. Finally, in a heterarchy the liberal aspect of the state is also strong. The horizontal accountability of executives by other autonomous state agencies reduces the risk of misusing state power and the encroachment of rights of non-state actors (O'Donnell 1999; Schedler 1999). Independent judiciaries, with the powers of judicial supervision, rules that make the changing of basic rights an arduous task, prevent executives from arbitrary decisions and force them to honor and make non-state actors to honor the laws. The existence of autonomous state agencies that can force incumbents to honor specific rules of using public resources, state agencies that represent specific rights or the rights of specific minority groups further extend the accountability of executives.

Democracies are 'heterarchic' to different degrees, depending on the methods of translating votes into seats, on the way representative bodies are organized, on the way powers are distributed among the different levels and branches of the government, on the existence of autonomous state agencies that can force incumbents to honor the basic laws, and the pre-established rules of making laws. In an established heterarchy, the existence of well-organized autonomous groups in the civil society and the economic society, and the proper functioning of free press further extend the accountability of executives within the state.

3.

After seven years of experimenting with neo-liberal economic reforms, most observers of the Russian economic developments see Russia is in a deep economic crisis and reforms producing anything but a market order ${ }^{4}$ According to surveys, Russian entrepreneurs do not trust the judiciary to enforce contracts and the state to uphold safe property rights (Brunetti 1998). Only economic actors within the safe heaven of robust networks undertake more complex economic transactions. The most elementary form of economic exchange plays the dominant role within the Russian economy, barter. According to official estimates, 75-85 percent of all transactions is' carried out without using money - either in the form of barter, mutual non-payments, ar with the use of money surrogates (Nekipelov 1998). As one could see from a World Bank's survey, the credibility of government's commitment to preserve market order is the lowest in the world in the former Soviet Union, much lower than in the Sub-Saharan Africa, or in Latin America (Brunetti 1998). Correspondingly, investment in the formal sectors of the economy is continuously

\footnotetext{
${ }^{4}$ See from within the rapidly growing literature on the Russian reforms the following works: (Aslund 1999; Brezinski, et ai. 1996; Gaddy, et ai. 1998;Johnson 1997; Kuznetsov 1997; Lazear 1995; Nekipelov 1998; OECD 1997; Popov 1998; Popov 1999; Solnick 1998; Treisman 1998; Woodruff 1998; Woodruff 1999).
} 
very low, the shadow economy is in increase, and capital flight is high (Stiglitz 1999). Depending on the closeness to the state, on the strengths of the network to which the firms belong, business leaders can routinely count on different, mainly extrabudgetary forms of help - either in the form of the toleration of the nonpayment of taxes, of social security ar the toleration, if not the support by the state of the non-payment of the utility bills or wages (Ickes 1999; Nekipelov 1998; Treisman 1998). Finally, while any meaningful regulation of asymmetries in economic power is absent, large economic conglomerates can easily use the state to get regulations that increase their chances to siphon away resources from the politically weaker sectors of the economy (Stiglitz 1999; Thornton 1997).

Russia inherited from the disintegrating Soviet Union a weak state, highly distorted economic structures and powerful industrial and regional lobbies - networks of firms and lower level state agencies interested in maintaining the status $q u o$. As in many other former soviet republics, Russian liberalization and privatization strategies did not lead to the emergence of market order. Instead, the neo-liberal reforms have further weakened the state, they have contributed to the collapse of economic order and further strengthened those lobbies, which are now based on networks of cross-ownership structures that link together firms, banks, financial institutions and state agencies.

After the demise of the Soviet Union, Russia had a weak state, with low capacity to maintain rule of law and uphold property rights (Hellman 1998; Kuznetsov 1997; Polishchuk 1997; Popov 1999). At least as importantly, Russia did not have a state capable of producing balanced policies, i.e., capable of accommodating a variety of interests, considerations and rationalities in a balanced way. The Russian constitutional system allowed for extreme centralization of executive power. After the resolution of the conflict between the President and the Supreme Soviet by tanks, the new constitution allowed for the fusion of executive and legislative functions, left without any serious judiciary supervision. Thus, within the Russian state there were no elements of either the separation of powers, or that of the checks and balances (Weisman 1995). Given weak accountability of politicians, decision-making about economic and social issues has not allowed or forced executives to consider ex-ante the manifold social, political and economic consequences of their policies. Because of weak accountability, the state executive has had very low levei of credibility or capacity to organize encompassing alliances around programs of economic transformation. As such, it was extremely vulnerable to capture by powerful economic groups. Altogether the Russian constitutional order was perhaps the most uncongenial from the viewpoint of creating a balanced economic order (Stark and Bruszt 1998; Weingast 1995$)^{5}$

At the time of the imposition of the first wave of radical reforms in 1992, Russian reformers were aware of the weakness of the state bureaucracy and of its low capacity to maintain rule of law, create and uphold encompassing regulations of

\footnotetext{
${ }^{5}$ See also Brunetti, et ai. for empirical data on the same issue (Brunetti 1998).
} 
economic activity (Polishchuk 1997). However, they strongly believed that liberating economic activity rapidly from the state would create a strong market order, and with it, the economic basis of strengthening the state (Polishchuk 1997). Moreover, they have strongly believed that profit oriented actors in the market pressed by efficiency considerations will anyway create the missing institutions necessary for corporate governance (Schleifer \& Robert 1998). They perceived the low levei of the accountability of executives as an asset from the viewpoint of fast reforms - in their view it allowed for the imposition of radical reforms, without allowing the opposition of reforms time to organize.

The calculations of the Russian reformers have been proven wrong. The Russian firms, never exposed before to competition, were unprepared for the radical shock caused by the sudden liberalization of prices and trade. Thousands of firms beca:me insolvent, a crisis of non-payment unfolded that dragged even the better performing firms into the crisis. The positions of these later firms were further aggravated by the fact that they could not get credit for the survival and restructuring from the fledgling capital market. The hastily created capital market did not function as expected - because of the weakness of the state. The capital market could not channel savings to the better firms. Because of the weak capacity of the state to uphold their rights and enforce contracts, small investors did not trust banks, and the banks that had very weak incentives to play any role within the real economy mistrusted private sector firms. Large networks of interdependent firms, entire sectors and regions found themselves in crisis, making in the end the weak and divided state to intervene and help out firms, sectors and regions - at the price of printing money.

The first intervention of the state, in the form of massive bailouts by the Central Bank, resulted in part from state weakness caused by internal division between the President and the Supreme Soviet. But the practice of subsidies has continued even after the strengthening of the presidential prerogatives by tanks. The practice of subsidizing firms, sectors and regions was based on printing money until 1995, after that only the methods have changed. Instead of helping firms on the 'expenditure side', after 1995 the emergence of a 'strong-ruble block' that was based on the alliance of the federal state and several powerful lobbies, has allowed for longerterm stabilization, at the price of helping the same groups now on the 'revenue side' (Treisman 1998; Woodruff 1998). After 1995 the state allowed selected groups of firms not to pay taxes, social security, or their utility bills and tolerated their accumulation of large wage arrears. The form has changed, the content remained the same groups of firms could have the stable expectation that they can count on the help of the state. Hyperinflation was gone, at the price of a further weakening of state capacity to collect taxes, and pay its organs to maintain rule of law and enforce contracts. The practice of bailouts directly contributed to the further weakening of the states' capacity to say no to powerful economic groups. The help given to selected groups of economic actors has further weakened the incentives of the better performing enterprises to get profit by way of restructuring and by way of sound investments of financial capital. Instead, it has sent them the signal, that 
the 'state is for grab'. lt became their vital interest to accumulate political capital in order to improve their position in the struggle for subsidies and special beneficial regulations. In this struggle only those companies, banks and regions had the chance to use the state to take resources away from the politically weaker sectors and regions, and from their increasingly poorer compatriots that were bigger in size, that could credibly threaten the state with considerable economic and political harms in case of their financial collapse.

Some of the networks of firms, banks and financial institutions were there already at the starting of the radical reforms. After the remova! of the branch ministries, whole sectors have organized into networks of cross-ownership partly in order to stabilize their economic positions, and partly to stabilize political positions within what was called the "bureaucratic market" (Johnson 1997; Kuznetsov 1997; Polishchuk 1997; Karlova 1997 ). ${ }^{6}$ These branch based 'Financial Industrial Groups' (FIG's) were complemented by another, even more powerful types of FIGs, organized by mainly Moscow based banks with closer ties to the government. The third type of networks was formed by regional and local state agencies. They were deprived of their economic powers at the beginning of the reforms; on the other hand, they became increasingly responsible for coping with the social and economic dislocations caused by the policies of the center. In order to maintain social and economic order, the only option available was to regain economic control over the largest firms under their previous contrai, now by buying the shares of these firms. This allowed them to work out strategies to maintain and stabilize local and regional economies by way of using the old routines of bargained planning and redistribution. Also, it was this strategy of the local and regional 're-nationalization' of property, that allowed local elite to save the most profitable assets from buy-outs by the more and more predatory Moscow based FIGs and it was the building up of powerful local and regional conglomerates, that has improved their bargaining power vis-à-vis Moscow (Stoner-Weiss 1997).

These associative institutions would have come about even without the weakness of the state. Exposed to the radical reforms, interdependent firms, banks and state agencies used these institutions to find ways of survival and adjustment by sharing the costs and the risks of their strategies. State weakness, however, has contributed in two different ways to their growth and strengthening. On the one hand, the weakness of the state to maintain the rule of law and enforce contracts compelled these conglomerates to "privatize"/internalize some of the functions of the state in order to substitute for the missing institutions of third party enforcement (Thornton 1997). On the other hand, the incapacity of the state to say no to powerful economic groups has made it each group's vital interest to build effective alliances with the state faster than other groups. Only success in this regard can

\footnotetext{
${ }^{6}$ Several of these FIGs were created and/or licensed by the state that tried initially to use them as devices of industrial policy (Karlova 1997).
} 
increase their competitive power in the struggle first solely for rents, and later increasingly for benevolent regulations and policies.

Once these groups caught the state, both the state and the economic actors got into a vicious circle. The state, captured by the FIG's came under greater and greater pressure to behave the same way as the predatory networks, i.e., to get revenues wherever money was visible. This has further contributed to the de-monetization of the economy. Still profitable firms have become reluctant to employ cash in their payments or even to use the banks for money transfers. Bankers are afraid that by making their transactions visible, the state might deprive them of their profits. As economic actors 'went informal', it became for the state harder and harder to get revenues, and it was forced to behave in a more and more predatory way, contributing solely to the further undermining of market order.

The second, and even more depressing result of state capture, was the 'de-diversification' of the revenue basis of the state and with it, its bigger and bigger dependence on the groups that have captured it. States, like the Russian, that was captured by powerful economic groups cannot help the coming about of a diversified revenue basis. Just to the contrary, with their policies furthering solely the interests of the largest lobbies, they contribute to the weakening and vanishing diversity of their own revenue basis. The further this process advances, the bigger will be the dependence of the state on these conglomerates. When only a small number of FIGs can provide the state with some cash, for the state to deliver there are no other options than to serving them ${ }^{7}$.

The incapacity of states in many of the postcommunist countries to say no to such networks has to do partly with the relative balance of forces between states and the associated economic actors. The more distorted were economic structures, the more radical were the reforms, the bigger was the pressure on economic actors to ally and 'go for the state' as their dominant strategy of survival. The other factor explaining incapacity of states to say no has to do with the level of accountability of executives. Executives that are not forced by autonomous institutions within the state to consider a diversity of interests in their decisions are easy prey for powerful economic groups. In other post-communist countries, the existence of contending forces representing different visions of social change and priorities for allocating state resources, executives were more capable to say no to particularistic groups and make balanced policies (Stark and Bruszt 1998). In Russia, and many of the former Soviet Republics, there were no institutions within the state that could have tied the hands of executives, counterbalance the pressure of FIG's and thus increase states' capacity to say no. In countries like Russia, by contrast, neo-liberal reforms did not lead to the emergence of a market order and they did not improve the chances of these countries to better adjust to a globalizing world economy. The

\footnotetext{
${ }^{7}$ E.g. in Russia, the Gazprom delivers roughly $20-25 \%$ of all the revenues of the Federal State. It is one of the most powerful political players in the country, controlling political parties and part of the mass media.
} 
mixture of distorted economic structures, weak states and radical reforms resulted in the emergence of an economic (dis)order in which upholding of property rights and the enforcement of contracts is clone if at all by non-state institutions, capital markets function only in very elementary way, productive markets and the state are controlled by powerful economic groups, and the capacity of states to regulate relations among economic actors gets weaker and weaker. Firms' market orientation is weak; they have little incentive to invest in the formal sectors of the economy, or to engage in more complex forms of economic transactions

Once caught by powerful economic groups, the state displays increasingly antidevelopmental features and with its activities just further deepens the developmental trap. It becomes the prime mover of the strengthening of FIGs' power, and by de-diversifying its own revenue basis it just deepens its own dependence on these networks.

After nearly a decade of the struggle to liberate economic activity from the state, Russia and most of the former Soviet Republics now face the question of how to liberate the state. If they want to create a functioning market order, they will need a state that is capable of upholding economic freedoms equally, and that is capable of regulating the highly uneven distribution of economic power in a balanced way. They need states that have the capacity to finda balance between public concerns of the day, and long term developmental considerations; between the interests of the regions and the interests of the national economy; between the need to maintain competition on the domestic markets, and the requirements of competitiveness on the world market; between the interests of the small-scale producers and the interests of the large corporations; between the interests of the consumers and the interests of the producers; between liberty and the misuse of liberty. They need states that have the capacity to say no to powerful economic interests, and intervene in the interests of the public. They need states that have the capacity to produce a wide consensus about developmental goals, and about the distribution of rights and obligations to attain these goals. They need states that have the power of breaking alliances among powerful economic actors, and that have the capacity to forge new alliances around visions of economic transformation that are based on the balanced association and accommodation of heterogeneous interests. In order to re-balance their economies, they have to re-balance their states.

In Russia, one can see only very preliminary attempts to re-balance the state, to balance public policy between contending interests, to strengthen its capacity to say no to the powerful economic groups. One of these attempts was the introduction of the 'double key' system in the budgetary decisions: 'if a motion to increase spending is initiated by the President's office, it must be endorsed by the Cabinet, and vice versa' (Polishchuk 1997). Instead of cutting the hand of the state, as the proponents of laissez-fair would have suggested, this solution tried to use the idea of the separation of powers to increase the capacity of the state to say no. The President could easily indicate an inability to pay: 'I would !ove to give, but I can't, I only have one of the keys to the treasury, and before opening it, I have to take into account the considerations of the Cabinet too'. Though this solution could not 
work in Russia where the President controls the government, it should be noted that in principle it was a move in the right direction. Behind this attempt, one can detect the two major ideas of those 'Founding Fathers' that have constituted the first national market order in the World. The first idea is to make the government credibly commit itself to preserve market order and uphold the universal freedoms of economic actors, other branches and levels of government should tie its hands ${ }^{8}$ The second and strongly related idea is at least as important. The separation of powers, together with the right institutionalization of checks and balances, is the guarantee, that particularistic interests will not easily capture the state. The different levels and branches of government have diverse representations of what constitutes the public good, and if to the extent they have the capacity to hold executives accountable they can reduce the probability that the government will serve particularistic interests solely. It is the diverse representations of the public good within politics that prevents the state from exclusively advancing the interests of particularistic groups. Furthermore, it is the extended accountability of executives within the state that institutionally guarantees decisions balanced between competing interests.

Russia and several of the former Soviet Republics, have still a long way togo to arrive at inclusive interest representation and public policy. Without major constitutional change, it seems that Russian policymakers will fail at that task, precipitating negative consequences for economic development. Attempts to transform the economic networks into developmental alliances or agents of strengthening state capacities to manage challenges to the capitalist order were unsuccessful. In Russia, the attempt to create a developmental alliance made of the largest bank-led FIGs and the state based on the common interest in economic stabilization and strang ruble, has conspicuously failed by 1998 (Treisman 1998; Woodruff 1998). The FIG's might have an interest in helping the state to stabilize the currency and increase its capacity to uphold their freedoms, but they are not interested in helping to bring about a state that could control them. ${ }^{9}$

The inclusion of the leaders of the most powerful regions into the working of the government, might be read as an attempt to 'diversify the portfolio of representations of public good' within the state in order to counterbalance the otherwise monopolistic representation of the concerns of FIGs (Solnick 1998). Contrary to the FIG's, regional leaders might be easily convinced to join a developmental alliance that would strengthen the federal states' capacity to get the FIGs under contrai. On the other hand, they have limited interest in increasing the powers of the

\footnotetext{
${ }^{8}$ According to the American 'Founding Fathers', nothing could be more damaging for the consolidation of a market order than the concentration of all powers in one branch of the government. If the same branch of government can decide about taxes and tariffs, state expenditure and about the laws maintaining economic freedoms, nothing could prevent the state from arbitrary interventions (Hamilton, et ai. 1961) See also the works ofNorth and Weingast on the same issue (North 1989; Williamson 1994).

${ }^{9}$ This would be as if the U.S. government would have asked the Camegies and the Rockefellers at the tum of the last century to join an anti-trust alliance.
} 
Federal State to uphold universal rights, and thus constitute a national market order (Solnick 1998). Without a major redistribution of rights and obligations between the federal state and the region, the regional networks have limited interest in strengthening the liberal aspects of the federation. The FIG's, on the other hand, would prefer to see a liberal laissez-fair state, but they have few incentives to support the advent of a state capable of regulating market contracts. Major constitutional change based solely on an alliance between the state and the lobbies without bringing in new actors to political change is not very likely. Increasing the social responsibilities of the federation might help to dissociate at least part of labor from the FIGs. Strengthening trade unions and the organizations of civil society might be functional for the emergence of new political players. Changing the conditions of pouring Western aid into Russia, spending more on building social security system and labor market institutions might contribute to the weakening of FIGs' political basis, and it might also reduce the amount of free money directly going to them via the Federal State.

\section{4.}

From the viewpoint of economic development, the problems countries like Russia face is not the one faced at the present by the economically most developed countries, i.e., how to reduce the direct economic interventions of states otherwise having rabust capacities to uphold universal rights of social and economic actors and regulate their relations in a balanced way. It is closer to the reality to see these countries facing at the same time the problems the United States had at the end of the $18^{\text {th }}$ Century and at the end of the $19^{\text {th }}$ Century. The first was the problem of creating a state capable of upholding universal rights and thus capable of constituting a functioning national market order. This required finding the type of distribution of powers among the different branches and levels of government that best helped the upholding of economic freedoms and with it the creation of a national market order. The second was the emergence of corporate capitalism, the problem of coping with the economic developmental problems of the rapidly growing inequalities in the distribution of economic power. This required the re-calibration of the power distribution among the different levels and branches of government ${ }^{10}$ ln both cases, it took several decades of social and political clashes to find a solution to these problems ${ }^{11}$

10 On the political dilemmas of creating a national economic order, besides the Federalist Papers, Bernard Manin's paper offers an insightful analysis. On the second period see the work of Sklar (Hamilton, et ai. 1961; Manin 1994; Sklar 1992).

${ }^{11}$ Note, that in the first case, the real clashes came decades after the approval of the Federal Constitution e.g. decades after its ratification. The Federal State had to send troops to North Carolina to preserve its prerogatives in collecting taxes. In the second case, the introduction of the first anti-trust regulations after a decade of social and política! clashes, signified but just the ending of the first stage of struggles 
In this paper, I have tried to demonstrate that there is a homology between constitutional design of policy-making and the overall characteristics of economic development. Countries which are less heterarchic, in which power is concentrated and states lack the capacity of producing balanced policies are easy prey for particularistic interests and thus contribute to imbalances if not to lock-ins of economic development. States, on the other hand, that have the institutions that allow for the production of balanced policies, are not the hostages of the actual distribution and intensity of preferences within the society, they have the capacity of rebalancing power relations within the economy and contribute to balanced economic development. Diversifying the representations of public good within the state and extending the accountability of state actors can thus contribute to the diversification of options of economic development, and can increase the overall adaptability of the economy.

\section{REFERENCES}

ASLUND, A. (1999) 'Why Has Russia’s Economic Transformation Been So Arduous?', World Bank ABCDE Conference, draft.

BOURDIEU, P. (1981) 'La Representation Politique. Elements pour une Theorie du Champ Politique', Actes de la recherche en sciences sociales 37(Feb.-Mar.): 3-24.

BREZINSKI, H. D., FRITSCH, M. (1996) The Economic Impact of New Firms in Post-Socialist Countries: Bottom-up Transformation in Eastern Europe. Cheltenham, UK; Brookfield, US: E. Elgar.

BRUNETTI, A., KISUNKO, G. WEDER, B. (1998) 'Credibility of Rules and Economic Growth: Evidence from a Worldwide Survey of the Private Sector', The World Bank Economic Review 12(3): 353-84.

COMMONS, J. (1924) Legal Foundations of Capitalism. New York: Macmillan.

DAHL, R. (1971) Poliarchy: Participation and Opposition. New Haven: Yale University Press. DAHL, R. A. (1956) A Preface to Democratic Theory. Chicago: University of Chicago Press. DOWNS, A. (1957) An Economic Theory of Democracy. New York: Harper.

DURKHEIM, E. (1989) Division of Labor in Society. Macmillan.

GADDY, C. A. I., WEINGAST, B. (1998) 'Russia's Virtual Economy', Foreign Affairs 77(5). HAMILTON, A., MADISON, J., JAY, J. (1961) The Federalist Papers. New York: The New American Library.

HELlmAN, J. (1998) 'Winners Take All: The Politics of Partia! Reforms in Postcommunist Transitions', World Politics 50(2): 203-34.

ICKES, B. W. (1999) 'Detour on the Road to Market: Roots of the Virtual Economy and its Evolution'. paper prepared for the conference 'Ten Years after the Fali. What Have We Learned About States and Markets', San Diego, April 1999.

JOHNSON, J. (1971) 'Russia's Emerging Financial Industrial Groups’, Post-Soviet Affairs 13(4): 33365 .

KARLOVA, E. (1997) 'Financial-Industrial Groups, Industrial Policy, and Competition in the Russian Federation', p. 127-44 in I. Lieberman, Nestor, S., Desai, R. (ed.) Between State and Market: Mass Privatization in Transition Economies: The World Bank/Organization for Economic Co-Operation and Development.

about the right redistribution of the powers among the different levels and branches of government to cope with the problems of corporate capitalism. 
KUZNETSOV, Y. (1997) 'Learning in Networks’, p. 156-77 inJ. Nelson, Tilly, Ch., Walker, L. (ed.) The Post-Communist Political Economies, Washington D.C.: National Academy Press.

LAZEAR, E. P. (1995) Economic transition in Eastern Europe and Russia: Realities of Reform. Stanford, Calif.: Hoover Institution Press.

LINZ, J. \& STEPAN, A. (1996) Problems of democratic Transition and Consolidation: Southern Europe, South America and Post-Communist Europe. Baltimore: John Hopkins University Press.

MANIN, Bernard (1994) 'Checks, Balances and Boundaries: the Separation of Powers in the Constitutional Debate of 1787', in Fontana, Biancamaria (ed.) The Invention of the Modern Republic. Cambridge: Cambridge University Press, pp. 143-59.

NEKIPELOV, A. (1998) 'The Nature of Russia's Economic Catastrophe-An Alternative Diagnosis', Transition 9(5): 5-8.

NORTH, D. \& WEINGAST, B. (1989) 'Constitutions and Credible Commitments: The Evolution of the Institutions of Public Choice', in Empirical Studies in Institutional Change, Lee J. Alston et ai. (ed.) London: Cambridge University Press, p. 134-65.

O’DONNELL, G. (1994) 'Delegative Democracy',]ournal of Democracy 5(1): 55-69.

O’DONNELL, G. (1999) 'Horizontal Accountability in New Democracies', in Schedler et. ai. (ed.) The Self-Restraining State: Lynne Rienner Publishers. p. 29-53.

OECD (1997) 'Economic Surveys 1997-98, Russian Federation 1997’: OECD.

OFFE, C. (1984) 'Competitive Party Democracy and the Keynesian Welfare State', in C. Offe (ed.) Contradictions of the Welf are State: Cambridge, Mass. MIT Press.

POLISHCHUK, L. (1997) 'Missed Markets: Implications for Economic Behavior and Institutional Change', in J. Nelson, Tilly, C., Walker, L. (ed) Transforming Post-Communist Political Economies, Washington D.C.: National Academy Press. p. 80-102.

POPOV, V. (1998) 'Output Change During Transition: The Role of Initial Conditions and Economic Policy', Voprosy Ekonomiky 7 (in Russian), p. 1021-47.

POPOV, V. (1999) 'Internationalization of the Russian Economy: What Went Wrong', Emergo, Journal of Transforming Economies and Societies 5(2): 53-85.

SAMUELS, W. (1992) Essays on the Economic Role of Government. New York: New York University Press.

SCHEDLER, A., DIAMOND, L., PLATTNER, M. (ed.) (1999) The Self-Restraining State: Power and Accountability in New Democracies. London: Lynne Riener Publishers.

SCHLEIFER, A. \& V., ROBERT (1998) The Grabbing Hand:Government Pathologies and Their Cures. Cambridge: Harvard University Press.

SKLAR, Martin (1992) The Corporate Reconstruction of American Capitalism, 1890-1916. New York, New Rochelle, Melbourne, Sydney: Cambridge University Press.

SOLNICK, S. (1998) 'Russia Over the Edge', Eastern European Constitutional Review, 7(4): 126-32.

STARK, D. (1999) 'Heterarchy: Distributed Intelligence and the Organization of Diversity', forthcoming in Paul Dimaggio, Walter Powell, David Stark and Eleonore Westway (ed.) The Future of the Firm. The Social Organization of Business.

STARK, D. \& BRUSZT, L. (1998) Post-Socialist Pathways: Transforming Politics and Property in Eastern Europe. New York: Cambridge University Press.

STIGLITZ, J. E. (1999) 'Wither Reforro?', World Bank Annual Bank Conference on Development Economics. Paper presented at the World Bank Annual Bank Conference on Development Economics, Washington D.C., April 28-30, 1999.

STONER-WEISS, K. (1997) Local Heroes: The Political Economy of Russia Regions. Princeton: Princeton University Press.

STREECK, W. (1997) 'Beneficial Constrains: On the Economic Limits of rational Voluntarism', inJ. R. Hollingsworth, Boyer, R. (ed.) Contemporary Capitalism-The Embeddedness of Institutions. Cambridge: Cambridge University Press. p. 179-219.

SUNSTEIN, C. (1985) 'Interest Groups in American Public Law', Stanford Law Review 38: 29-58. THORNTON, J. (1997) 'Restructuring Production Without Market Infrastructure', in J. Nelson, Tilly, 
Ch., Walker, L. (ed.) Transforming Post-Communist Economies. Washington D.C.: National Academy Press. p. 133-56.

TREISMAN, D. (1998) 'Fighting Inflation in a Transitional Regime: Russia's Anomalous Stabilization', World Politics 50(2): 235-65.

WEINGAST, B. (1995) 'The Economic Role of Political Institutions:Market Preserving Federalism and Economic Development', The Journal of Law, Economics and Organization 11(1): 1-31.

WEISMAN, A. (1995) 'Notes and Comment: Separation of Powers in Post Communist Government: A Constitutional Case Study of the Russian Federation', The American University Journal of International Law and Policy (Summer 1995), p. 1234-55.

WILLIAMSON, O. (1994) 'The Institutions and Governance of Economic Development and Reform' in Proceedings of the World Bank Annual Conference on Development Economics, Washington, D.C., p. 171-97.

WOODRUFF, D. (1998) 'Why Market Liberalism and the Ruble's Value are Sinking Together', Eastern European Constitutional Review, vol. 7(4), Fali 1998, 132-39.

WOODRUFF, D. (1999) 'Institutional Theory, Russia and the New Politics ofEconomic Backwardness', St. Petersburg: European University, unpublished manuscript. 